\section{教育機関 (大学) めぐり}

\section{によせて}

\section{粉档に対する認識}

アメリカソビエト両国でおとなわれている宇宙ロケ ットの開発は，日一日と華々しい発展をとげて，祅わ 机の目をみ灿らせるものがある。だが，繁雑で精密を極 队施軌道の追跡や，宇宙船の操絣士の活躍は報道されて 清，口ケットの本体や然料などについては，一般にはほ とんぞ知られていない。とくに，激しい温度変化侕元 る弾頭部や高温飞さらされるノズルに用いられる酎熱材 料を法じぬして，自動操繸や観測や通信につかわれる 光学的あるいは電気的な機珹の中心部にまで，数えきれ ないほぞの新しいセラミクスやガラスの材料が使われて わり，ロケットの開発が，てれらの新しい無機材料の発 達によって支えられているてと起理解しているのは,一 群の専問家にすざないだろう。そとに，ひとつの大きな 閵題がひそんでいるのである。

セラミクスの新しい傾向とエンジニアリング・サイエ ンス

以上のとと牥ひとつの例にすぎないが，とくに最近に なって，妿ラスを含めてセラうクスの材料には，いまま での構造的な材料という概念からはなれて、レー・ザー・ ガラスとかサーミスタとかチタン酸バリウム磁器などの 例にみられるように，次第に機能的な材料にまで発展し ようとする著しい傾向がみられまたセメント関係でも 酒期的な性質をもつ材料がつよく要望されている。しか え，《の方向に材料の発展を推進するためには，いまま でにも增して，物質に対して基濋的でしかる広い科学的 知識党もった技術者や研究者を数多く養成する必要があ り，アメリカを站じ好とし日本でも，数年来，大学の 工業教育にいくつかのエンジニアリング・サイエンスを 設定し，材料の新しい発展に対処しようと努力してきて いる。

\section{学生数減少の傾向とその原因}

ところが，このようなととと全く反対に，大学の也ラ 汶クス含む無穖材料関係の学科や講座に応募する学生 の数が，近年になってやや減少するがみえる傾向があ り，さだめられた定員数を下まわり，あるいは第二志望 の学生か洎されてくるようなととも，残念ながら事実と して認めざるをえない。

てのような動向は日本だけでるく欧米にもみられると てろであるが，その原因のひとつとして次のようなとと が挙げられよう，従前の大学の基整的な教育では，古典 菂な無機化学が台とな鸟，化学反応や物性に関しては
液体，気体を主とし て，固体あるいは固 体村料について统触 れるととらか沙なか った。しかるに，有 機化学の方面で位体

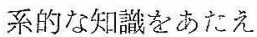
ることわ比較的容易 である上に，石油化 学の藍々しい発脿方之 学生の眼をうば。 た。るちろん，最近 亿なって，和機材料 関係の基礎科学 的進 歩したし, 石洞化学 ほどに表面䩸々し くないが、一逨の二 ュー・セラミクスや 新種のガラスにみら れるように，電子工

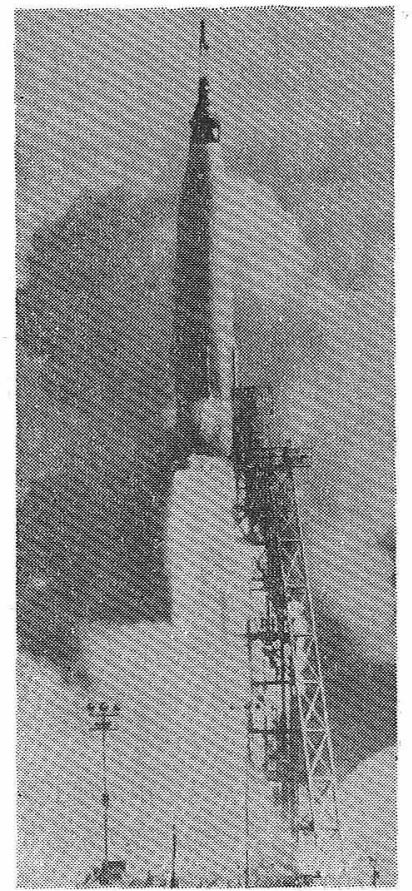
業や原子力工業など

への，新しい機能をもった無機仏料の発展は，乙れを静 かな革命と呼んでもよいだらう。しかし，てれらのとと が，どれだけ一般理解されているだろうか。そと， もうひとつの原因がひそんでいよう。

\section{その対策之“教育機関めぐり”}

以上のような傾向を見すでしにするならぼ，今後 10 年とたたないうちに，無機材料工業の発展亿致命的な陵

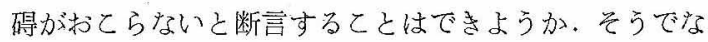
くとも，学界と産業界と㕝問わず，優秀な人材集集方 ととの困難さは世界的にみられる傾问であり，各分野と もにその対策には窗心している奏情である。さいわい， 無機材料の分野では前述のよう亿学界，産業界々もに新 しい機運にむいており，問題はただそれを如何にして一 般竍報らせるかというととに尽きる。

今回，「大学めぐり」が企画されたのも，䈍業を含む 無機材料工学について, 関係劣る全国の大学の教育と研 究活動を紹介し，大学化進学するものに対しては学科を 選択するための正確な知識を与光，また研究機閶当よび 産業界々対しては，研究の分担とその動问敀育方針广 ぞについて，詳細に知っていただくための参考資料を提 供するととにあったが，それだけでなく，筧菐を合む無 機材料と，その工業の現状や将来の発展性，またそれに 関係する大学の新しい教育体制などについて，すっとよ く一般のひとびとにも認識される必要を暏感する次第で ある、数干年にさかのぼる窐業の重苦しい后統を，輝か しい未来へ向っての前進の糧に変えるために. 


\section{(1)}

\section{東京 I 業大学}

\section{まえがを}

東京の西南, 大岡山のスロープに，夕陽に紅く映光て そそり立つ時計塔の景観は鋭く印象的である。その前身 の蔵前の東京高等工業学校汃 引昭和 4 年に昇格したの 前後して，当時としては東洋でも有数の規模をもった， 合理性を象徽するような鋭角的なビルディングが出現し た、以来 30 年，壁面には永い風雪の跡がきざまれたが ヒマラヤ杉は黒ぐろと見上げる者を压し，秋には銀杏の 並木みちに黄金色のじゅうたんか晸かれ，春には桜の花 かす为侍計塔も埋もれて、いま多変らぬ若者たちの希 望の学園となっている.

てのキャンパスの中に理工学部と工業材料研究所をは じすとする 3 つの研究所があり，学部約 2400 名, 大学 院 400 余名の学生夌収容し，教授以下 700 余名の躘員 が教育と研究の指導にあたっている、学生数に対して職 員の数の割合の高いととは全国一で，学生 1 人あたりの 教育予算の多いととと共にひとつの特長となってい る.他方，日本育英会その他の奖学金の補助马半数近い 学生が受けている。また学部の学生に対しては寄宿舎の 設備があるが，定員の関係上，一部のものに限られてい る。

理工学部には機珹工学系学はじめとして8つの系があ り，それそれれの系にいくつかの学科か浙属している。

\section{無機材料工学科}

との学科は織維工学科标よび金属工学科とともに材料 工学系にはいっている。その前身は䆝業学科とよばれ， 歴史は古く，ほとんど明治初期の本校の創立にまでさか のぼる、日本に扔ける工業の発展と歩家をともにしてき

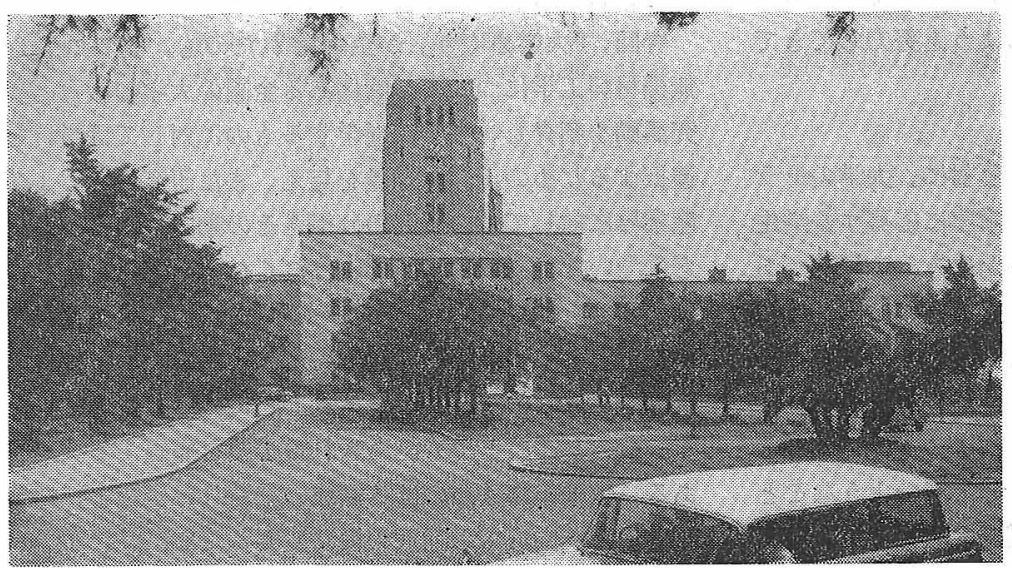

露工業大学 本館
ただけに，当学科の先辈はみな空業その他の産業界の重 鎮として活躍している.

䉑業はエジプトの昔から存在して。ひとびとに馿れ漞 しまれてきただけに，か壳って近代工業として理解され ていない傾きがある。しかし，冒頭の総説にもあるよう

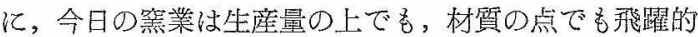
な進展をとげており，とくに過去における単なる構造的 な用途から脱却して，新たな物性に基づく機能的な材料 の分野にまでふみてもうと努打をはらっている。てれと 歩調をあわせて, 昭和 35 年, 本学行材料工学系か澵設 されたのを機会に，その中で，無機材料工学科として新 しい使命のもとに再出発した次第で苏る。

との学科には，あとでのべるように4講座があって。 卆業諭文の学部の学生を各年度について 25 名, そのほ か大学院の学生起同しく 12 名いれるととができる。新

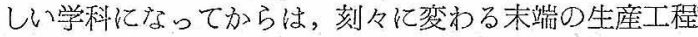
などの紹介より，むしろますます高度化する科学，技術 消化し，乙れによ。て自から新材料および新技術を開 発できる力を乌光ることを目標に，エンジニアりング。 サイエンスによる能率的な教育方式をとり入れ，化学動 力学, 固体化学, 高温工学, 粉体工学など, 材料科学々 しての内容をるった講義に重点が扔かれている。また学 部之研究所の無機材料関係の大学院学生を中心に，ブり ンドレー教授を記念するセミナーを月 2 回開き，教授か ら学生まで討諭に参加して，活きた教育成果をあげてい， る。

つぎに，各講座について紹介をとてろぬよう。

第 1 講座（川久保正一郎教授，嫍生謙次講師）

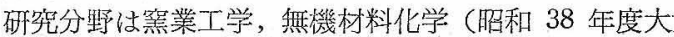
学院学生募集要項所揭) など. 現在，杂業論文の学生が 2 名いるが, 大学院学生はいない。

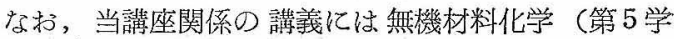
期・川保教授)，弿業学第 1 (第 6 学期・素木教授，川

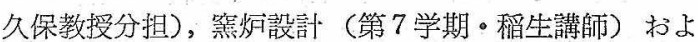
び大学院に無機材料化学特論がある.そのほか化学工学 実験江は地質鉱物学講座を除〉第 1 , 第 2 , 第 3 の学部 3 講座押よ び工業材料研究所の各部門が分担 参加している。との数年来，低学 年の化学第 1 ，第 2 および化学实 験第 1 ，第 2 亿第 1 講座が参加し ているのは，教官の事情によるる のであって, 無機材料工学科と直 接の関係はない?

請座内に特殊な装㹂活あまりな いが，手製または研究室で組立て た装置认は，自記記録式熱分析装 置，1秒読みスペクトロメー夕学 


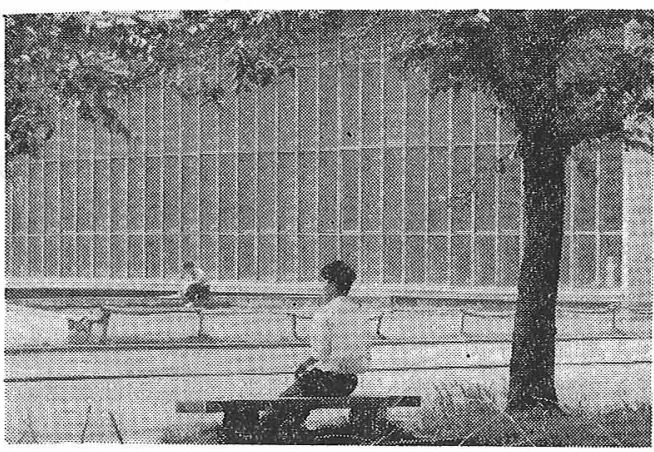

学園風景（背後の新講堂）

改装したゴニオメトリックフォトメータなどがあり，前 者注主として“焼成石高の風化現象飞関する基礎的研 究”に, 後者は主として反射光强度の角度分布の測定 に，それぞれ使用された。ガラス表面を対象とし研削材 粒子の自然落下による攻賃の発生を反射光の角度分布方 ら追跡し，種々な表面硬度の測定と比較検討を行ない， また研磨過程特々弗酸溶浓仗よる化学研磨の過程の追求 が同様な手段で行なわれた。

その他, 炎光光度計, 光電比色計, ポーラログラフ, イオン交換樹脂，有機溶媒抽出法などを組合せた分析法 の研究が，鴳業関係の原枋料，製品などを対像としてお こなわれている。

第 2 講座（素木洋一教授，古田博諵師）

本講座では学部で物理化学的, 化学工学的見地汃らみ た䇺業製品の製造工程，製品の特性と試験方法，わよび 粉体工学について講義を行ない，大学院ではレオ、ジー そ物質の微構造について教育している，従って，研究も この内容浪って行なっている。

講座には，なお宇田川助手，大津賀助手があり，共通 の研究題目に対してそれぞれの立場方ら実験を行なって いる、すなわち (1) 物理的, 化学的処理および加熱処理 による無機物質の 相変化とそれに伴子う趾買の变化， (2) 化学工学的処理汶対する 原料の基本的性質の研究， (3) 粉佮々関する流動，成形，焼結など関する研究， および (4) とくに粘土や岩石の未利用資源の活用研究を 取上け゚ている。これらの㰢究に必要な機器や装置はほと んぞ完備している、たと光ば基本的な研究のために分光 $\mathrm{X}$ 線分析，X線解析，偏光拈よび反射顯微鏡，各種粒度 分析装置と表面積測定装置，空気量測定装置，遠心分離 機，粒度分析装置， $Q x-$ 夕, C x一夕，超絶緣抵抗計 などの電気特性測定装置, 各種熟天秤々熱分析装置, 熱 膨脹計, 白色度計, 透光度計, 各種レオメー夕, 熱伝導 度測定器, 粒子凝集追跡装置などの実験室用機器類, 製 造工程研究用としてフィルタープレス, クネットマシ ン, 微粉研機, 粗研機, 真空土練機，ムーラー混練機， パッグミル，ロールミル，重油炉，強度試験機などを設 㣁している、装置類は研究の一助として手製のものも多 w.

現在，基整実験を完了し，工程研究に移しているもの は, 製造では軽量骨材, 軽量タイル, 酎火軽量謏瓦, 水 処理剤などで，工程研究としては連続滤過方式，粘土を 含む硫酸などの廃液の処理方式，振動による逴続成形法 などである．基礎的な間題としてはアルナイト，ディカ イト，パイロフィライト，ヒブシャイト，サーペンティ ン，ゼオライト，シェール，珪灰石などの处理方法によ る構造と性質の変化汇関する研笲を行なっており，その 一部は完了している。

要するに态講座では天然多量に産出する非金属無機 原料の特性を知り，穴の性質を生かした工業材料と製品 の製造化およずそれ伴なう廃寨物処理方法の研究を主 体にとりあげている。

第 3 講座（森谷太郎教授，境野照雄助教授）

無嘰材料全般を通して，乙の講座は熔融現象，具体的 にはガラス，珐郎などの分野を主とした工業的な研究の ほがガラス状熊，ガラスの内部構造，融液やガラスの 結晶化現象，ガラスの着色現象などの理諭的な解析にも 努力をはらっている。

講座には，学引滝沢一貴助手，山本孝子技官が扔り， また森谷教授は同時に本学の工業材料研究所長を亲兼称 ている. 現在, 4 人の大学院学生と 4 人の卆業論文の学 生があり，てのほか炕常時 5 6 人の研究生も，それぞ れ研究を分担している。

昭和 33 年度に文部省の機関研究費を受けてから,引 きつづき新しい耐熱材料であるデビトロセラミクスに関 して、あら的る角度加ら研究をすす好て来ているが、その なかで，リシウム・弗素金零取利用した強度の高いデ ビトロセラミクスやフォトセラムのケミカル・マシー ニングの過程を対像とした，二理碳りシウム結晶化物の 勒酸による侵蝕の研究䒚どについては，非常に興味ある 成寒が得られている。ガラスの着色性工芸方面に広く利 用されているが，との講座では，着色現象をガうスの内 部構造から得られる有力な情報と考光て，研究に利用す る立場をとっている、銅，銀，金，白金などのコロイド に上る着色については，それぞれの金属が，ガラス中で 光化学的あるい熱的にイオンから逻元されて凝等し，

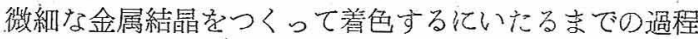
の解析，また，ク口ム，バナジウム，チタンなどの謰移 元素による着色では，资れらによって生ずる分光吸収 と，着色イオンの配位子の種類や状馝などの関係の究明 が抢となわれている。ささらにガラスの内部構造の研究に ついては，菻谷教授によって提唱されているガラス微相 説は国際的にも高く評保されて斿り，その他，固体反応 や粉体の混合，不均質混合体の研究などもおてなわれて いて, 研究の範围㛎きわめて広い，したがって，講義の 面でも, 工業的なるののほ方沉, 材料物性（森谷），固 
体化学 (森谷, 境野)，䉑業第2（ガラス状態諭，境野） など，無機材料，つまり広い意味のセラミクスの基礎に 重点をおき，教育ならびに研究活動を推進している。

講座内では毎土曜日に教授から学生や研究生まで，全 員が集まって，その 1 週間に得られた笑験結果について 相互にディスカッションを势てない，それ基づいて次 週の実験計画をたてるシステムをとっており，てのほか 大学院の学生を中心とするグループ，あるいはそれに卆 業論文の学生を加えたグループなどによって，それぞれ 活溌なセらナーがおこなわれ，相互の討論をとおして活 きた教育効果が挙げられている。

大学院, 学部々も例年, 定員の上で若干の余裕があり， 気鋭の学生の参加加望まれている. なお, 助手について も1名の欠員があって，広く人材が求められている。

地質鉱物学講座 (山四久夫教授, 岩井津一助教授) 研究活動次のテーマの諸砄究を行なっている。

(a) 接触裂成岩の研究

(b) 粘土鉣物の研究（生成環境, 鉣物学的性質, 工 業利用など)

（c）高温状態における物質の構造の研究

(d) 金属酸化物の燒結 および相変化に関する研究 $\left(\mathrm{MgO}, \mathrm{ZrO}_{2}, \mathrm{Al}_{2} \mathrm{O}_{3}-\mathrm{SiO}_{2}\right.$ 系など)

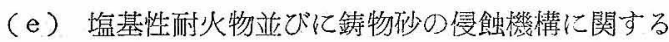
研究

（f）本邦火山地域における檟出物，変柯物などの基 礎的工業的研究 (火山ガラス, 浮石, 火山灰, そ の他の微絊鉱物について)

以上の目的のため

（a）偏光顕微鏡（ユニバーサルステーシ，積分求積 器)

(b) X線回折用装置（ディフラクトメータ，結晶趈 転カメラ，ワイゼンベルグカメラ)

（c）化学分析，蓺変化測定装置（示差蓺分析，蓺天 秤，熱膨脹計など)

などにより，鉣物学的見地に立脚し，天然わよび人工の 無機物質を対象とした基礎的研究と，その無機材料およ

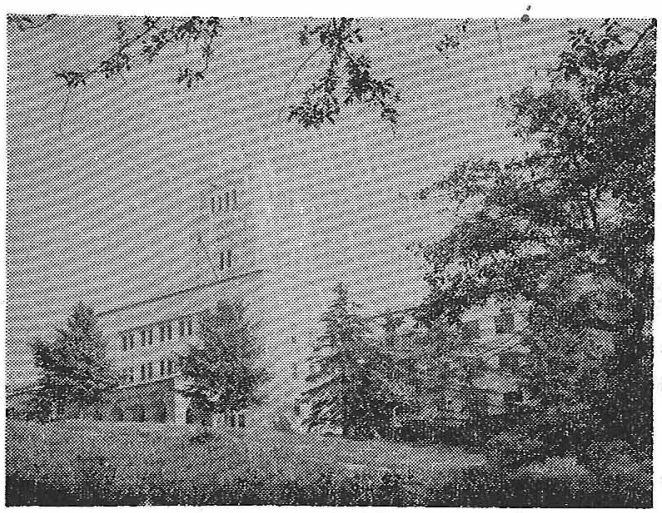

夕陽产浴びる時計塔
び䈍業方面への利用の研究とを行なっている。

教育活動 本講座で担当している講義並びに学生㬰 験の項目は次の通りである。

a）地学第一（一般教養を目的とした広範囲の地学

b ）地学第二\}講義)

c) 結晶学

d) 結晶学実眏(偏光顕微鏡わよびX線回折法の垁習)

e ) 珠酸塩平衡論

f) 高温操作 (後半が当講座担当で高温物性を含めた 鉱物工学)

g) 鉱産原料特論（大学院講辛）

を行なっている。さらに当研究室に扔ける，鉱物学的取. 扱い法枋よび研究方法の瞨及を目的とした顕微鏡，X線 結晶学の上級ゼそナーを随時行なっている。

このほか現在卆論学生 1 名, 研究生 1 名力浙属し, ま た大学院学生は昨年度杂業 1 名 (昭和 37 年度博士コ一 ス杂，現在本学原子力研究施設助手）があった。

その他鉱産資源の調査，火山活動の観測，桨害予 防などの目的のために, 適時現地調查に出動することも。 古当。

講座内には，ほが浜野健也助手，小坂丈予助手わよ び大場立夫技官があり，研焭に，奏験の指導に活躍して いる。

無機工業材料に密接な関係をもつ講座あるいは研究室 としては, 学部になお, 化学工学系工業化学科の無機工 業化学講座と原子炉研究淤設の鈴木研究空とがある。

\section{鈴木研究室}

本学原子炉研究施設には原子炉材料を専攻する一部門 が設けられており，黒田教授，鈴太助教授か担当してい る。黑田教授は金属材料を，鈴木助教授は非金属材料を 担当しているが，本誌の性格上後者に焦点を合わせよ う. 鈴木助教授が以前より無機材料の研究に從事してき た閶係から，本研究室では炭化ウラン，炭化ジルコニウ 么, 黒鉛等を含む原子炣材料の他に窒化珪素, 炭化轨 素, アルミナ, マグネシア等の高温物理化学および高温 物性の研究が行なわれている。高温度における測定が重 要であるので，研究室では種々測定装置の製作を心掛け てきたが，現在活動中のものに黒敛抵抗炉 $\left(2400^{\circ} \mathrm{C}\right.$ 以

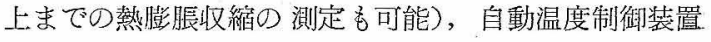
を附帯するモリブデン弱，都市ガス・プロパンガスー酸

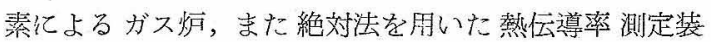
置，雾围気が制御できる高感度熱天秤測定装置等があ る. 他に雪結晶質炭化珪素熱体を用いた炉 ( 2 基)， 3 武料を同時に測定できる熱膨脤収縮測定装置また表面 組織の観察に必要な反射顕微鏡, 自動伥磨器などがあっ て常時使用されている. 現在, 約 $2000^{\circ} \mathrm{C}$ 附近まで蓺伝 導率の測定装置の試作か竐画されており，高周波誘導炻 の製作が予定されている．上に述べた研究事項に鈴木助 
教授をはじぬ木村助手, 研究生 4 名が協力して従事して いる. この研究室の杂業生は三菱セメント, 旭ガラス, 日本板ガラス，三井金属，小野田セメント，徳山曹達等 に就職して活躍しており, 優秀子学生諸氏が共に研究に 励すととを我々は希望している。

無機工業化学講座 (久保輝一郎教授, 谷口雅男助教授) 本講座は，ひらく無機工業化学のうち，金属工業など の分野を除いた以外の分野を内容とするものである・し たがって, 研究のテーマとしては応用固体化学, 応用X 線, 無機化学工業における諸問題をとりあげている. 主 なものは

a）粉体の物性主として無機物粉体について, 化 学反応性（固一固, 固一液, 固-気), 燒結性, 触媒性, 吸着性の研究，超微粉体の製造など.

b) 応用X線最近虫高温振動式 X線回折計, ガス 流通式高温X線回折計の製作を行ない，高温状態の 結昆構造・組織, 高温に预ける化学反応 (固一固, 固一気)などの研究を行なっている。

c) 無機粉体の活性化による有機化合物の重合反応.

d）硫酸関係 工業廃硫酸の回収之含有金属の利 用，発煙硫酸の濃度さ比重の精密測定，砂鉄から心゙ ナジウムの回収など.

久保教授の担当講戔络無機工業化学, 同特論(応用固 体化学), 応用X線, 工業化学概論. 杂業諭文学生 3 名, 大学院修士課程 4 名, 同博士課程 1 名, 就職先は広く化 学工業一般で, 各種の業種に分布している。

\section{工業材料研究所}

本学には以上の理工学部における各講座あるいは研究 室のほかに，無機材料を主要な研究対象とするこの研究 所がある。

当工材研は旧空業研究所と旧建築材料研究所が，昭和 33 年 3 月 31 日統合整備し設置されたものである. 年々 進歩する各種工業材料の組織構造あるいは物理的化学的 性質に関する研究成果をあげ，またてれ学総合的に応用

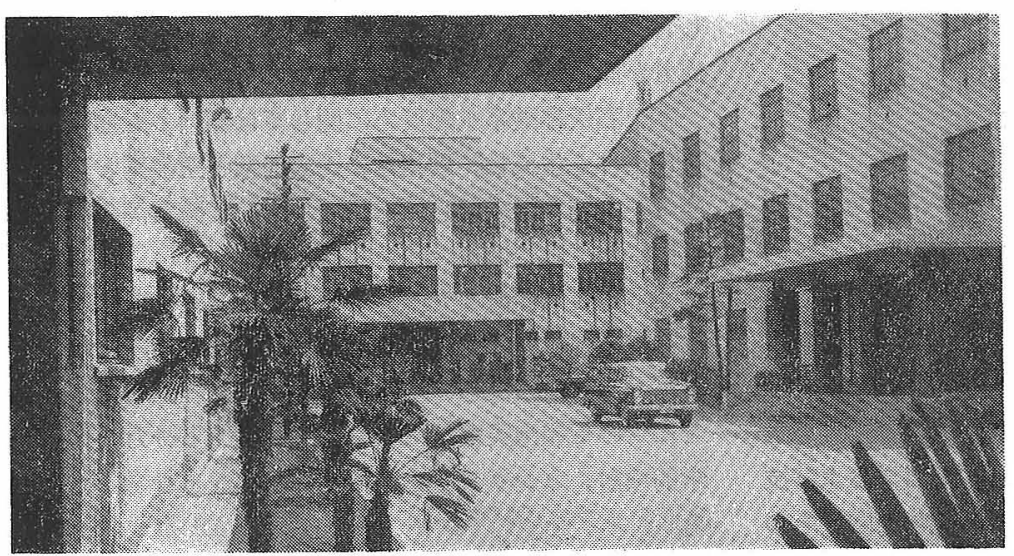

工䒹材料研究所
する新しい研究を進めるため, 両研究所は共に急速に充 実㤝化する必要を生じ，学問研究の発達状沉に即応し， 重複を整理し発展的に解消し新しい構想に基づいて新発 足した。旧窑業研究所は昭和 18 年 2 月 1 日設立され, 目的として「䇺業に関する学理および応用の研究」をあ げている.一方旧建築材料研究所は「建築用材料に関す る学理方よび応用の研究」を目的とし, 昭和 9 年 2 月 28 日設立されたものである。

工枋研の規模は公的には 6 部門, すなわち定員数は教 授 6 , 助教授 6 , 助手 12 , 技官 6 , 雇員 3 加ら構成さ れ，事務系職員数 10 となっている. 所長仙初代内田 俊一前学長, 二代山内俊吉前学長学経 $\tau$, 三代河䲴千尋 教授，現在四代目に当り森谷太郎教授によって統括され ている.工材研は資源化学研究所, 精密工学研究所之共 にキャンパス南地区研究所地带にあり, 建物はコンクリ ート 3 階建本館をはじめ工場群などを含め延 $3138 \mathrm{~m}^{2}$ と なっている。

工材研は学部之同一キャンパス内にあり，歴史的にも 而者の関係は密接で, 教育面にもかなり関与し, 大学院 学生, 卆論学生および研究生の数は年々 30 名近い. 今 年より超高温材料部門の設置が決まり，また計画として 固体化学, 複合材料, 電子材料などの設置も要求中であ り，建設材料を含め無機工業材料に関する世界的水準の 研究所としての発展を期している.各部門あるいは研究 室の特徽, 研究内容と成果などは下記の通りであるが, 他に工場・共通施設があり, 研究実験装置の設計, 製作 および一般工作，大型材料試験機の管理などに当ってい る。

無機材料第一部門 (河鴆千尋教授, 斎藤進六助教授) 最近の宇宙技術の開発, 原子力および電子工学などの 目覚しい発展によって，セラミクスを中心とする耐熱材 料, 超硬材料, 耐蝕材料, 核燃料, 構造材料, また, 電 子機器用のエレクトロニクス, とくに絶緑材料, 強訸電 材料, 磁桦材料, 半導体その他高周波諸特性を利用した 新しい応用分野がつぎつぎと開拓され始すている。

この部門では, 在来の一般陶磁 器, 耐火物および断熱材関係, そ の他新しく開発されたてれらの特 殊セラミクス祆料の学閔的体系の 確立とその原料処理, 成形および 焼結を対鱼とした製造技術, 燒結 物の機械的, 熱的, 電気的および 化学的諸性質などの材料物性と微 構造との関連などについて光学な らびに電子顕微鏡, X線的研究な どが行なわれている。

[1] 耐熱构䊉, 特殊害業品に 関する研究として, (1) $\mathrm{Al}_{2} \mathrm{O}_{3}$ ， 
$\mathrm{ZrO}_{2}, \mathrm{ThO}_{2}, \mathrm{MgO}, \mathrm{Cr}_{2} \mathrm{O}_{3}$ など純酸化物 セラえクスの 焼結と物性（電気抵抗測定，発熱体，半尊体，七ラ之ク ス工具などの基礎的研究を含む)，(2) $\mathrm{BaTiO}_{3}$ 系強誘電 体，(3) プラズマジエットによる超高温の発生とその工 学的応用, (4) リフラクトリー,セラミクコーチング, 化 学蒸着などによる耐熱被缼，電気䋓縁，(5) $\mathrm{TiC}$ の生成 および TiC 系サーメットの接結, (6) $\mathrm{Cr}-\mathrm{O}$ 含有系の相 平衡とクロム系耐火物, (7) 耐熱, 耐摩部品（ブレー午 材など)の暁結之特性，(8) BN など硯素化物，珪化物， 窒化物，炭化物など，(9)球状粉体の㹈造，(10)八イドロ スタチックプレス，(11) 熱間成形法などがある。

[II] その他として (1) 熱伝導率, 比熱の測定, (2) 電 子顕微鏡に上る粘上鈗物の形貌, (3) 多孔質素地, 軽量 骨材, (4) 断熱材, 而火断熱材, (5) 化学磁器, フラン樹 脂系セメントモルタル，(6) 珪肺，石綿肺に関する紛塺， (7) 実験計画法，品質管理などの研究がある。

研究室の日常を斎藤研究室の例で見れば，当研究室は 助教授斎藤進六, 助手宗宮重行, 大学院愽士課程, 修士 課程各 1 名, 研究生 3 名, 杂論学生 2 名を主軸として抒 り，人員構成のバランスもよくとれている，每水曜日に は各自の研究結果の報告と今後の研究を討諭する䂙究会 議，外国文献の紹介を目的とする輪講会があり，10 㭙

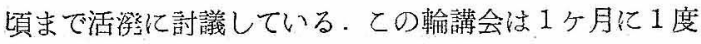

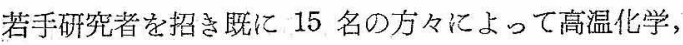

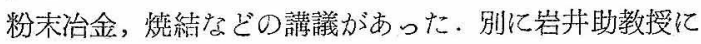
よるX線結晶学の講義が每週 1 回あり, 結晶学の理解出 来る研究者を䒺成している。

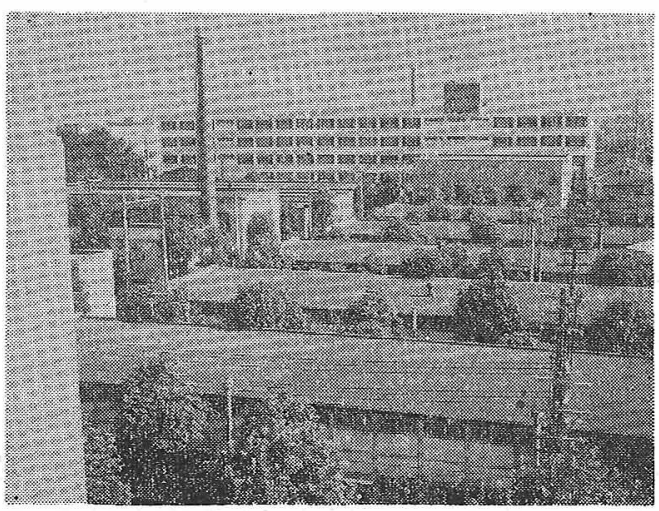

新館と実驗工埸群

次期を亿なう学生を大切亿するので，かれらはバラ色 亿輝く研究室で青春をエンショィしつつ，またよく勉強 している。

無機材料第 2 部門 (田賀井夸夫教授, 近藤連一助教授) 本部門では䈏業の中で伝統的工業枋料·しして重要な耐 火物，セメントなどの製造と特性に関する科学および技 術の広い範园を扱っている．研究対象が地味な関係その 他で卆諭や大学院の学生として配属される者の数が余り
多いとはい光ないが，卆業生の多〉は㰾火物，タイル，

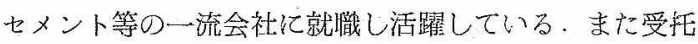
研究あるいは再教育のため研究生として会社から派遗さ れ研究に從事している者は比較的多い，本部門の助手と して毛利純一，毛利尚虔分研究々突験指導に当ってい る。

まず耐火物については高純度マグネシアの橴結と拡 散，ドロマイト㳡火物の組織とスラダアクションの関係 などが検討されている。ママグネシアに関連し潮解甠のな い新しいマグネシアセメントについても研究している。 また附火物の熱輻射学增し耐久性を高めるコーティング 材についての研究を完成している。

銅線にフリットを薄く焼き付ける方法で而熱性をもち フレキシブルな絶縁電線分得られた。これから発展し， アルミニウムパネルの美観と耐久性を向上させるために 婇赏掛ける研究を行ない成功起収めた。この研究でアル ミニウムと婇の間に大きな熱起電压の生ずる事実を発見 しており，将来実用に役立つことが期待される。

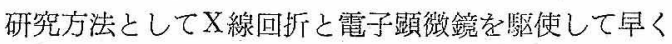
から成果をあげて来たが，最近X線マイクロアナライザ 一を忘用して耐火物の侵蝕㙨構や婇の失透現象を解明し ている、独特を装置として赏心力で高温の融液を分傩す

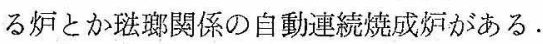

㳄にセメント化学としてはセメントの硬化理諭, 新し い型のセメントの可能性，粉体とか多孔流の性質さらに 関連材料として人工軽舅骨材，鉄筋防蝕などについて研 究し檴義毛行なっている，従来の研究成果と現在手がけ ている課題は大要炊の通りである。

(1) 高硫酸塩スラグセメントの初期強度と中性化傾向 を改良した無収縮セメント学得ている：強膨脤セメント について主要構成化合物の結晶解析を行ない, その水硬 性を理論付け，また同型をとる 20 余りの新化台物老見 出し各種物性についての検討を進めている。

(2) ポルトランドセメントクリンカーの焼成化確率対 応法を適用して要因を解析し，あるいは反応速度を検討 し, さらに $\mathrm{MnO}_{2}, \mathrm{TiO}_{2}, \mathrm{P}_{2} \mathrm{O}_{5}, \mathrm{CrO}_{3}, \mathrm{SO}_{3}$ など特殊 成分が諸狌質に及ぼす影響についても調べている。

(3) 石灰珪酸系水熱反応に関しては原料の鉱物組成， 処理条件と生成物，硬化体の比表面積と空陌率および強 度などの関係を究明し，特に原料として硫黄㳯の適合性 を明らかれしている。

(4) 均質高性能な人工軽量具材を得るたるの基礎研究 として原料䊀を急熱し熱伝達, 熱伝導, 反応熱, 粘性, 粒径预よび重量などの変化を求め，また純鉱物の組合わ せについて発泡実験を行ない組織を調べる一方，化学工 学的検討,コンクリートの特性の研究なぞを進わてい る.

蠎結材料部閏 (清浦雷作教授, 佐多敏之助教授) 
金属の熔融による冶金に対して粉末冶金があるのに対 疬して，ガラスのような熔融窒業品に対して粉末の焼結 によって作られる筧業品がある。しかし，ての区别は簃 密なものでなく，陶磁器のよう亿熔融ガラス部分を多量 亿含む燒結材料も広い意味で存在する，本部門ではガラ ス部分がほとんどない烧結材料について新製品の試作お よび性能の解明改良の研究を行なっている．現在まで行 なって来，なお現在行なっている研究について述べよ う.

酸化物サーメットの研究：酸化物と金属とか顕微鏡的 に微細な状態で相互に分布して完全に烍結した状態にあ る材料か酒化物サーメットである．本研究室ではこの異 質原材料の煋結の方法について詳しくしらべ，燒結体の 強度, 化学性物理性の特徵と微構造との関連について研 究を行なっている、特に機械的衝撃強度を強化するため の諸条件についてしらべている.

無機材料のクリープ特性：高温用セラ之ク材料，特に 耐火物，耐熱材料（サーメット）の曲げクリープをしら べるため，6 試料を同時に長時間テストできる高温クリ ープ試䖍機を試作して $1400^{\circ} \mathrm{C}$ までの温度でクリープ試 験を行なっている.

酸化ウラン系原子炉用核燃䊀の研究 : 原子炬核燃料と して酸化ウランや炭化ウランが金属代代って動力炸に全 面的に使用されようとしているが，本部門では酸化ウう ン材料について $\mathrm{UO}_{2}-\mathrm{O}$ 系の. 高温平衡状態図について 研究を行ない, また $\mathrm{UO}_{2}-\mathrm{ThO}_{2}$ 系固溶体核燃料の研究 として，その焼結方法および酸素を過剩に含む非化学量 論組成の平衡状態図を作って核然料の種々の物性の基整 研究を行なっている。

酸化物の高温における物理化学的諸性質の研究：酸化 物の研究は従来 $1500^{\circ} \mathrm{C}$ 程度までの研究が多く，それ以 上，とくに $2000^{\circ} \mathrm{C}$ 以上の研究は少なく不正確なので, まず $3000^{\circ} \mathrm{C}$ 程度まで研究できるタングステン発熱体を 用いた高温炉を試作して高温における平衡の研究を開始 した. 今後は超高温における酸化物の各種物性の測定法 そついて研究を進める予定である。

本部門は，とのように純酸化物战よびそのサーメット 《ついて深く研究を進めてゆく汪化物，硫化物につい てもその焼結について一部研究を行なっている、今後無 機材料はその純度や性能について酷に要求されるように なり，また新しい用途例えば超高温隔熱材料，高真空や 高還元雾困気での材料, 電磁気材料等に発展しなければ ならないので，ての方面の広いかつ深い研究を急速に進 めね汸ならない，本部門は清浦雷作教授，および佐多敏 之助教授, 他助手 2 名, 技術員 1 名の小人数で構成され て研究の進度は思うように行かない現状である，教育面 では学部 4 年生, 大学院修士, 博士課程の杂業諭文研究 も学部研究室と同等に行なっておう, 講義, 実験等の指
導も行なっている。

化学冶金部門 (佐藤正雄助教授)

工業材料研究所誕生にあたり，学队扔りる名称蚛特 殊金属仏料部門として発足した．創設当初より希有元素 である希土類元素，ジルコニウム，チタン等の抽出，精 鍊なよびこれらの元素の応用などの研究を行なってき た. 第 2 次大戦後物質の精製方法の躍進的進歩により希 土類元素の分襍精製も比較的容易となり，相当純度の高 いものを工業的に利用する道も開けてきた。また，希土 類元素の個々のものがそれぞれ独自の性質をもつととも 注目されてきた。たと兊ば、イットリウム金属は融点が 相当高い上に軽く，原子炬にわいて発生する熱中性子に 対して非常に小さい吸収断面積をもっているのに，同じ イットリウム族に属するガドリニウムは非常に大きい财 収断面積をもっでいるなどその一例である。その他,最も 新しい磁性材料としてイットリウム鉄ガーネットは在来 のフェライトと結晶構造をまったく異にし，マイクロ波 亿用いる好適な磁性村料として明るい前途力滀束されて いる. 現在, ての部門では主としてィットリウム族元素 の性質とその利用について研究を行なってわり，すでに 弗化物浴よりの前記のイットリウム鉄ガーネットの単結 晶の試作に成巩している，主なる実験装置として自記示 差熱分析装置や自記光電分光光度計などを備えている。 職員の構成は助教授 1 ，技官 1 となっている。

固体物理部門 (竜谷光三助教授)

本部門の研究は各種工業材料の物理的特性に関するも ので，主として熱的特性である。中でも材料，構造体の 伝熟特性は現在までに約 30 年研究されている. 罴業関 係の研究題目としては a. 各種材料並びに構造体の伝熱 特性, b. 材料, 構造体の凍結障害等, c. 材料, 構造体 の熱膨脤性状， d. その他，材料の熱的性状に関する研

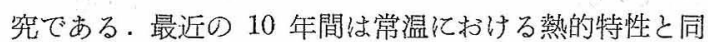

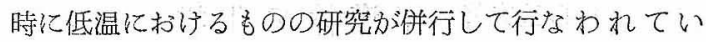
る。

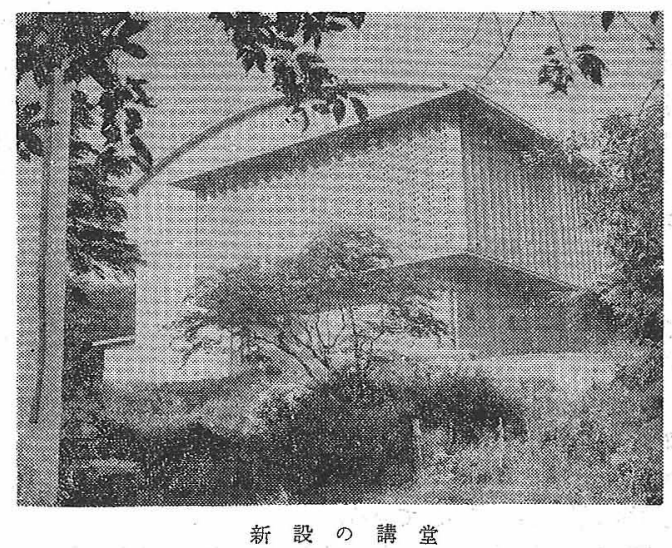

本部門関係の主なる設備は a. $6 \times 6 \times 4$ (高) $\mathrm{m}^{3}$ の恒 温恒湿実験公，温度 $-10 \sim+35^{\circ} \mathrm{C}$, 閶係湿度 $50 \sim 85 \%$ 
で, これらの範囲内で任意の 組合わせ 温湿度が 得られ る, b. $30 \times 60 \times 60$ (高) $\mathrm{cm}^{3}$ の低温槽, 温度 $-45 \sim$ $0^{\circ} \mathrm{C}$, c. $2 \times 2 \times 2$ (高) $\mathrm{m}^{3}$ の低温実験室, 温度 $-100^{\circ} \mathrm{C}$ 〜常温, 本邦で最低温の実験室である（昭和 38 年度完 载). 研究室は助教授 1 , 助手 1 (昭和 39 年度充足予 定) 研究補助員 2 , その他随時アルバイト学生によって 研究が邆行されている。

\section{材粘俯用部門 (後藤一雄.教授)}

素材を材料化するための基礎的研究，並びに応用研究 を行ない，合わせて，材料の生産方式に関する研究を行 なっている．特に材料化するに対し，単独のものを複合 化して，その目的に応ぜしめることが大切であり，ての 分野の研究に主眼を置き，用途面としては建設関係を主 として考慮に加えている。

基礎的研究——複合の理念，複合化の基礎的特性，複 合材料の強弱, 構造理論
応用研究一マスプロ建築用構成材料, 生産研究—アルミ中に異質材を埋設する方法, プレ キャストコンクリート成形法，グラスウールパネル 加工法

成 果一プレキャストコンクリート碓築, 金属マ スプロ建築, LP 鋼, エキスパンドハット鋼, 補強 アルミ材

\section{む す び}

東京工業大学における無機材料工学科と工業材料研究 所を中心とした教育と研究活動の概況は以上のとおりで ある. 無機材料工学を專攻しようとする学内外の学生諸 氏ならびに協同研究，再教育のための研究生の派遣，あ るいは卆業生の採用などについて考慮されている産業界 の方々に，いささかでも参考になれば幸いである。
(C 411 からつずく)

業基礎科学の面より，(13)，(27)，(28)の3 編は䇪業原料の見地から 重要な論文である。なお蜜業原料の鉱物組成を定量的に取扱う ことが重要視されている折からシンポジウムの 2 編の論文は極 めて貴重な文献である。勿論その他の論文といえども粘土の利 用, 研究に従事する者にとっては重要かつ興味あるものである ことは疑いない，ともかく本書は最近の粘土研究の動向を知る うえにおいても，また貴重な文献集としても常に座右に置きた い本である。

（宇田川重和）

\section{河口武夫著 半 導 体 の 化 学}

B 6 判, 219ページ，定価 550円 発行所：丸善株式会社

この書物著者の意図にのべられているように，化合物半導 体を中心にして現在までの研究結果，およびそれに関連する応 用の概要をのべたものである。半導体に関する邦書はこれまで 相当の数にのぼるが，多種の物質にわたって化学の立場から書 かれたものはあまり見当らない，そこにこの書物の特色がある といえよう。

1. 半導体化学の展望では, 歴史の紹介につづいて半導体(あ る(性固体) の電子的性質を理解するに必要な概念が説明され ている. 2. 単体半導体では $\mathrm{Ge}, \mathrm{Si}$ の実例で，いわばオーソド クスな半導体の電気的性質が解説されている.

3. 化合物半導体 (1) (金属酸化物) および 4. 化合物半導体 （2）(金属間化合物，有機化合物拉よび磁性化合物）だ忧，多く の化合物半導体の例でめぼしい実験結果と，とれに対する物理 化学的な解釈がのべられている。

窯業になじみ深いのは主として 3.の金属酸化物であるが，こ の部分は相当にくわしく書かれている.

5. では光導電性; 光起電力，整流作用；吸着現象がとりあげ
られている. 吸着現象は 6. 半導体触媒に関連して半導体の化学 に独特な分野であるう。

6. 注化合物半導体の応用であるが, 半導体触媒, 電子写真, 半導体ガラス（酸化物系のみ）の項にやや多くの紙数が与えら れている.

現在化合物半導体といわれるものには，その範围を無機物に かぎってみても，誘電体，絶縁物ともみられるイオン性化合物 から，合金あるいは半金属に近い金属間化合物まで含められる が，この書物は多方面なこの対象の現状を要領よくまとめてい る.しかしページ数の制約からフェライト関係, 半導体の製法, 精製が省かれている。

これまで化学方面から 固体材料を扱ってきた人が，半導体の ことを知る上にこの書物はガイドブックの役割を果すものと思 われる.各所に親切に示されている引用文献や，化合物の表はさ らに必要な問題をほりさげようとする読者には大そう役立つ.

一方 $\mathrm{Ge}, \mathrm{Si}$ から金属間化合物へとすすえできた物理方面の 人はこの書物から，まだ手がけていない酸化物の半導体の実状 を知ることができよう。このことは当然なことかも知れないが， 化合物半導体の研究は化学と物理とでは 異なった方針により異 なった方面から手がつけられていることを物語っている．この 書物はこのような事情を知るにも便利と思われる。

金属間化合物のあるものは半導体性に, あるものは金属的性 質になる理由を, 構造化学的に説明した Mooser \& Pearson

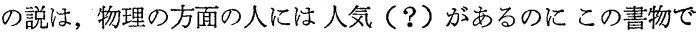
はふれられていない，これも両分野の雾囲気 のちがいによるの かも知れない.

製造関係が省かれているのは残念であるけれども，窯業方面 の技術者にとって手軽に活用できる書物としておすすめするこ とができる．值段も手頃といえよう.

（菅池季三） 